Article

\title{
The Characteristics and Genome Analysis of vB_AviM_AVP, the First Phage Infecting Aerococcus viridans
}

\author{
Hengyu Xi ${ }^{1,+}{ }^{+}$Jiaxin Dai ${ }^{1,+}$, Yigang Tong ${ }^{2,+}$, Mengjun Cheng ${ }^{1}$, Feiyang Zhao ${ }^{2}$, Hang Fan ${ }^{2}$, \\ Xinwei Li ${ }^{1}$, Ruopeng Cai ${ }^{1}$, Yalu Ji ${ }^{1}$, Changjiang Sun ${ }^{1}$, Xin Feng ${ }^{1}$, Liancheng Lei ${ }^{1}$, \\ Sadeeq ur Rahman ${ }^{3}{ }^{-0}$, Wenyu Han ${ }^{1,4, *}$ and Jingmin $\mathrm{Gu}^{1, *}$ \\ 1 Key Laboratory of Zoonosis Research, Ministry of Education, College of Veterinary Medicine, \\ Jilin University, Changchun 130062, China; m15543135579@163.com (H.X.); 15204525855@163.com (J.D.); \\ mengjun_c@163.com (M.C.); vetboss@163.com (X.L.); saycall850@126.com (R.C.); jiyalu120@163.com (Y.J.); \\ schangjiang@126.com (C.S.); xinple@163.com (X.F.); leiliancheng@163.com (L.L.) \\ 2 State Key Laboratory of Pathogen and Biosecurity, Beijing Institute of Microbiology and Epidemiology, \\ Beijing 100071, China; tong.yigang@gmail.com (Y.T.); yangfan10159532@163.com (F.Z.); \\ Fanhang11@gmail.com (H.F.) \\ 3 College of Veterinary Sciences \& Animal Husbandry, Abdul Wali Khan University, Mardan 23200, Pakistan; \\ sadeeq@awkum.edu.pk \\ 4 Jiangsu Co-Innovation Center for the Prevention and Control of Important Animal Infectious Disease and \\ Zoonose, Yangzhou University, Yangzhou 225009, China \\ * Correspondence: hanwy@jlu.edu.cn (W.H.); jingmin0629@163.com (J.G.); \\ Tel./Fax: +86-431-8783-6406 (W.H. \& J.G.) \\ + These authors contributed equally to this study.
}

Received: 31 October 2018; Accepted: 23 January 2019; Published: 26 January 2019

\begin{abstract}
Aerococcus viridans is an opportunistic pathogen that is clinically associated with various human and animal diseases. In this study, the first identified A. viridans phage, vB_AviM_AVP (abbreviated as AVP), was isolated and studied. AVP belongs to the family Myoviridae. AVP harbors a double-stranded DNA genome with a length of $133,806 \mathrm{bp}$ and a $\mathrm{G}+\mathrm{C}$ content of $34.51 \%$. The genome sequence of AVP showed low similarity ( $<1 \%$ identity) to those of other phages, bacteria, or other organisms in the database. Among 165 predicted open reading frames (ORFs), there were only 69 gene products exhibiting similarity ( $\leq 65 \%$ identity) to proteins of known functions in the database. In addition, the other 36 gene products did not match any viral or prokaryotic sequences in any publicly available database. On the basis of the putative functions of the ORFs, the genome of AVP was divided into three modules: nucleotide metabolism and replication, structural components, and lysis. A phylogenetic analysis of the terminase large subunits and capsid proteins indicated that AVP represents a novel branch of phages. The observed characteristics of AVP indicate that it represents a new class of phages.
\end{abstract}

Keywords: Aerococcus viridans; opportunistic pathogen; phage; genome analysis

\section{Introduction}

Aerococcus viridans is an environmental Gram-positive saprophytic bacterium that belongs to the Streptococcaceae family [1]. A. viridans resembles streptococci microscopically and often causes coinfections with streptococci [2,3]. Because it is often mistaken for staphylococci or streptococci, the pathogenicity of this bacterium has been underestimated [4]. In recent years, $A$. viridans has been observed to be clinically associated with different human and animal diseases [1]. A. viridans has been 
reported to cause infections in lobsters [5] and tilapia [6], and is associated with swine arthritis [7], swine meningitis [7], swine pneumonia [7], and bovine mastitis [8-11]. In humans, A. viridans is described as an opportunistic pathogen that can cause urinary tract infections [12], bacteremia [13], meningitis [14], septic arthritis [15], and especially endocarditis [16]. A. viridans has been reported to be increasingly resistant to most common antibiotics $[13,17]$ and, importantly, vancomycin-resistant isolates have recently been described [18].

Bacteriophages (phages) are bacterial viruses that specifically recognize, infect, and replicate inside host bacteria, with more than $10^{31}$ phage particles reported to exist in the biosphere [19]. This massive phage diversity has a marked effect on the environment, ecology, and bacterial evolution [20]. Owing to their specific bactericidal abilities, phages have been considered as therapeutic agents since the early 1920s [21]. However, the development of this therapy has lagged due to the wide availability of antibiotics [22]. In recent years, owing to the global emergence of multidrug-resistant bacteria, the study of phage therapy has experienced a renaissance.

Although bacteriophages of most described bacteria have previously been reported, including those for Escherichia coli [23,24], Listeria [25,26], Staphylococcus aureus [27,28], and Streptococcus [29,30], among others, no $A$. viridans bacteriophage has been described.

In this study, the first bacteriophage that specifically infects A. viridans, named vB_AviM_AVP (abbreviated as AVP), was isolated and characterized. A genome analysis shows that AVP has extremely low similarity to other phages, bacteria, and other organisms in the database.

\section{Materials and Methods}

\subsection{Bacterial Strains and Growth Conditions}

A. viridans AV-X1 was isolated from clinical specimens of meningitis-infected pigs and initially cultured on TSA (trypticase soy agar, Sigma, Shanghai, China) containing 5\% defibrinated sheep blood. The isolated strain was identified by 43 different biochemical tests (Table S1) (VITEK 2 Compact, France Bio, Mérieux, France) and was further confirmed as A. viridans by amplifying a 540-bp fragment of the 16S rRNA gene with the specific primer pair F (5'-GTGCTTGCACTTCTGACGTTAGC- $\left.3^{\prime}\right)$ and R (5'-TGAGCCGTGGGCTTTCACAT-3') [31]. The PCR product was sequenced and the resulting sequence was compared against the GenBank accession database using BLAST. The strain was stored in $30 \%$ glycerol at $-80{ }^{\circ} \mathrm{C}$ and was routinely grown at $37^{\circ} \mathrm{C}$ using a brain-heart infusion (BHI, Becton-Dickinson, Franklin Lakes, NJ, USA) medium.

\subsection{Isolation of the Aerococcus viridans Phage}

The isolated A. viridans strain AV-X1 was used as a host strain to isolate the phage from sewage samples. Sewage samples were collected from a sewer system (Changchun, Jilin, China) and were filtered with four-layer gauze. AV-X1 was cultured to the logarithmic phase in BHI broth until the $\mathrm{OD}_{600 \mathrm{~nm}}$ reached 0.6 , after which $\mathrm{AV}-\mathrm{X} 1$ and the prepared sewage samples were cocultured overnight in BHI broth at $37^{\circ} \mathrm{C}$. Subsequently, the coculture was centrifuged at $10,000 \times g$ for $10 \mathrm{~min}$ at $4{ }^{\circ} \mathrm{C}$, and the supernatant was filtered using a sterile $0.22 \mu \mathrm{m}$ pore-size filter (Millex-GP Filter Unit; Millipore, Bedford, MA, USA; LOT R6MA05262). To detect and purify the phage from the supernatant, a double-layer agar plate assay was carried out [32]. Briefly, a single spot was picked from the double-layer plate and added to $200 \mu \mathrm{L}$ of the host strain grown to the log phase for amplification in $5 \mathrm{~mL}$ of BHI medium, and the double-layer plate method was carried out after $5 \mathrm{~h}$. This was repeated three times to obtain the purified AVP phage lysate. The concentration of agar in the overlays was $0.7 \%$. The purified phage was amplified and stored at $4{ }^{\circ} \mathrm{C}$ and at $-80^{\circ} \mathrm{C}$ in glycerol $(3: 1, v / v)$.

\subsection{CsCl Density Gradient Centrifugation}

Following large-scale culturing, AVP was precipitated using 10\% $(w / v)$ polyethylene glycol 8000 and $1 \mathrm{M} \mathrm{NaCl}$. Next, the phage sample was placed at the top of a discontinuous $\mathrm{CsCl}$ gradient (1.32, 
$1.45,1.50$, and $1.70 \mathrm{~g} / \mathrm{mL}$ ) and centrifuged at $35,000 \times \mathrm{g}$ for $3 \mathrm{~h}$ at $4{ }^{\circ} \mathrm{C}$. The phage band was collected and dialyzed with a suspension medium (SM) buffer $(0.01 \%$ gelatin, $100 \mathrm{mM} / \mathrm{L} \mathrm{NaCl}, 50 \mathrm{mmol} / \mathrm{L}$ tris- $\mathrm{HCl}$, and $10 \mathrm{mM} / \mathrm{L} \mathrm{MgSO}_{4}$ ) at $4{ }^{\circ} \mathrm{C}$.

\subsection{TEM of vB_AviM_AVP}

Purified AVP was applied to 200 mesh copper grids and negatively stained with phosphotungstic acid $(2 \%, w / v)$. The morphology of AVP was examined by transmission electron microscopy (JEOL JEM-1200EXII; Japan Electronics and Optics Laboratory, Tokyo, Japan) at an accelerating voltage of $80 \mathrm{kV}$.

\subsection{One-Step Growth Curve}

After the addition of $100 \mu \mathrm{L}$ AVP solution $\left(3 \times 10^{7} \mathrm{PFU} / \mathrm{mL}\right)$ into $1 \mathrm{~mL}$ AV-X1 culture $3 \times 10^{7}$ $\mathrm{CFU} / \mathrm{mL}$ at an multiplicity of infection (MOI) of 0.1 , the mixture was incubated for $5 \mathrm{~min}$ at $37^{\circ} \mathrm{C}$. Next, the mixture was centrifuged at $10,000 \times g$ for $5 \mathrm{~min}$ at $4{ }^{\circ} \mathrm{C}$. The pellet was suspended in $10 \mathrm{~mL}$ of $\mathrm{BHI}$ broth and incubated at $37^{\circ} \mathrm{C}$ with shaking at $180 \mathrm{rpm}$, with samples collected every $5 \mathrm{~min}$ for the first $30 \mathrm{~min}$, and then every $10 \mathrm{~min}$ until $60 \mathrm{~min}$ to test the concentration of the phage. The first set of samples was immediately diluted and titrated using a double-agar method. The second set of samples was processed with $1 \%(v / v)$ chloroform for $30 \mathrm{~min}$ prior to phage titration to release intracellular phages to determine the eclipse phase [33]. The burst size was defined as the ratio of the total number of phages liberated at the end of one cycle of growth to the number of infected bacteria [34]. This experiment was repeated in triplicate.

\subsection{Sequencing and Bioinformatics Analysis of the AVP Genome}

After the large-scale amplification of AVP, the cellular material was removed by centrifugation at $10,000 \times g$ for $20 \mathrm{~min}$ at $4{ }^{\circ} \mathrm{C}$. Next, DNase I and RNase A were added to the supernatant at a final concentration of $1 \mu \mathrm{g} / \mathrm{mL}$ followed by incubation for $30 \mathrm{~min}$. The supernatant was collected by centrifugation at $10,000 \times g$ for $20 \mathrm{~min}$ at $4{ }^{\circ} \mathrm{C}$. AVP was precipitated overnight using $10 \%(\mathrm{w} / \mathrm{v})$ polyethylene glycol 8000 and $1 \mathrm{M} \mathrm{NaCl}$. The precipitated phage was resuspended in an SM buffer. Finally, an equal volume of chloroform was added for phage extraction, with the concentrated phage obtained after centrifugation $\left(4000 \times \mathrm{g}\right.$ for $15 \mathrm{~min}$ at $\left.4{ }^{\circ} \mathrm{C}\right)$. The genome of AVP was extracted using a viral genome extraction kit (Omega Bio-Tek Inc., Doraville, GA, USA) as per the instructions of the manufacturer. Whole-genome sequencing was performed at the Beijing Genomics Institute using IlluminaHiSeq 2500 sequencing. Newbler v.2.8 was used to assemble sequences, and the AVP genome was visualized using CLC Genomics Workbench software (CLCbio). Genes were initially predicted using the Rapid Annotation using Subsystem Technology (RAST) annotation server [35]. All predicted ORFs were manually verified by performing searches against the National Center for Biotechnology Information (NCBI) database using PSI-BLAST (the cutoff was 0.0001) and HMMER (HMMER web server: 2018 update) with a minimum $E$-value of $10^{-4}$ [36]. A tRNA scanner (http:/ /lowelab.ucsc.edu/ tRNAscan-SE/index.html) was used to analyze tRNAs [37]. The sequence alignment was generated using CLC Main Workbench, version 7.7.3 (CLC Bio-Qiagen, Aarhus, Denmark). The amino acid sequences of terminase large subunits and capsid proteins were aligned using PSI-BLAST with a minimum $E$-value of $10^{-4}$. The output was sorted according to the hit score, from which different phages having homology were selected and their nucleic acid sequences were obtained. The sequences were then classified according to the NCBI taxonomy database. The gene sequences of the terminase large subunits and capsid proteins were aligned with reference gene sequences using the ClustalW program within the BioEdit 7.0.4.1 package. Once aligned, the maximum likelihood (ML) phylogenetic trees were constructed using their nucleic acid sequences with 100 bootstrap replicates [38]. 


\section{Results and Discussion}

\subsection{The Characteristics of Aerococcus viridans}

The strain AV-X1, which was isolated from brain samples, formed small ( $\leq 1 \mathrm{~mm}$ diameter), circular, and translucent colonies with smooth surfaces with an off-white color and exhibited typical $\alpha$-hemolysis on blood agar plates, showing its role as a pathogen (Figure S1a). Microscopically, AV-X1 appears as groups of four Gram-positive cocci that are occasionally paired or clustered. Further identification via biochemical tests (Table S1) indicated that AV-X1 is most likely A. viridans, with a $97 \%$ confidence value. AV-X1 was ultimately confirmed as an $A$. viridans strain by $16 \mathrm{~S}$ rRNA gene sequencing (Figure S2).

\subsection{The Biological Characteristics of vB_AviM_AVP}

A novel phage, named as vB_AviM_AVP (abbreviated as AVP), was isolated from sewage using AV-X1 as the host strain. AVP formed clear plaques on BHI plates after coculturing with a bacterial lawn of AV-X1 (Figure S1b). Electron micrograph images of AVP indicated that it possesses isometric, icosahedral heads and contractile tails, suggesting that AVP is a member of the Myoviridae family, as shown in Figure 1. The diameter of the AVP head is approximately $94 \pm 5 \mathrm{~nm}(n=3)$, and the tail length is approximately $189 \pm 5 \mathrm{~nm}(n=3)$. A one-step growth curve of AVP infecting AV-X1 revealed an eclipse period of $10 \mathrm{~min}$, a latent phase of $15 \mathrm{~min}$, and a burst size of about 139 PFU per infected cell $\left(\left(4.18 \times 10^{7} \mathrm{PFU} / \mathrm{mL} \times 10 \mathrm{~mL}\right) /\left(3 \times 10^{7} \mathrm{PFU} / \mathrm{mL} \times 100 \mu \mathrm{L}\right)\right)$, indicating that AVP is an efficient phage, as shown in Figure 2.

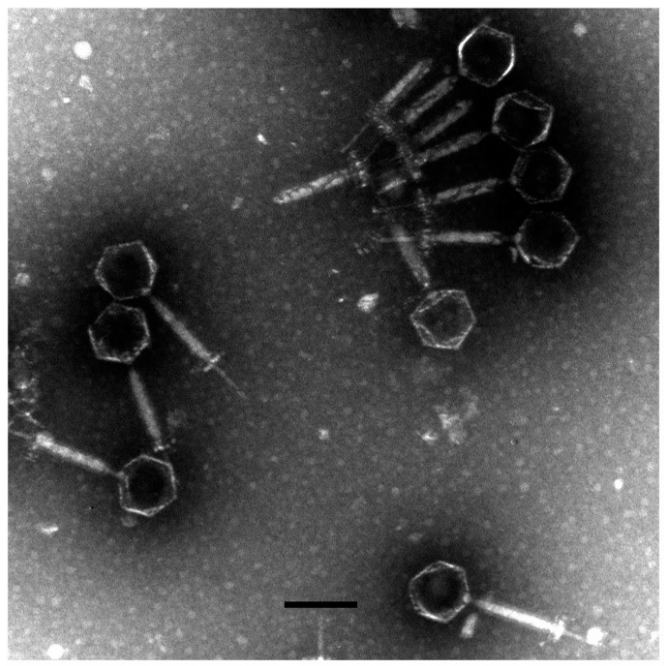

Figure 1. The morphology of vB_AviM_AVP (AVP). AVP was negatively stained with 2\% phosphotungstic acid (PTA) and examined by transmission electron microscopy (TEM) at an accelerating voltage of $80 \mathrm{kV}$. The scale bar represents $100 \mathrm{~nm}$.

\subsection{The General Characteristics of the AVP Genome}

The coverage of the genome is $100 \%$ and the average depth of sequencing is 3595.36 . The genome of AVP is a contiguous, 133,806-bp, double-stranded DNA sequence. The genome sequence of AVP showed low similarity ( $<1 \%$ identity) to those of other phages, bacteria, or other organisms in the database. The total G + C content of AVP was determined to be $34.51 \%$, which is significantly lower than that of its host, A. viridans (about 39.4\%) [39]. Five transfer-RNA-encoding genes were found in the genome (Table S2). A total of 165 putative ORFs were predicted in the complete AVP genome (Table S3), with ATG (135/165), TTG (24/165), and GTG (6/165) serving as start codons and TAA (100/165), TAG (58/165), and TGA (7/165) serving as stop codons. The genome order was set according to one of the determined termini. The open reading frames have a coding density of $86.45 \%$, covering a total of 
$115,681 \mathrm{bp}$, and the majority of the ORFs (114/165) were observed to be transcribed on the positive strand. The arrangement of the entire genome is shown in Figure 3.

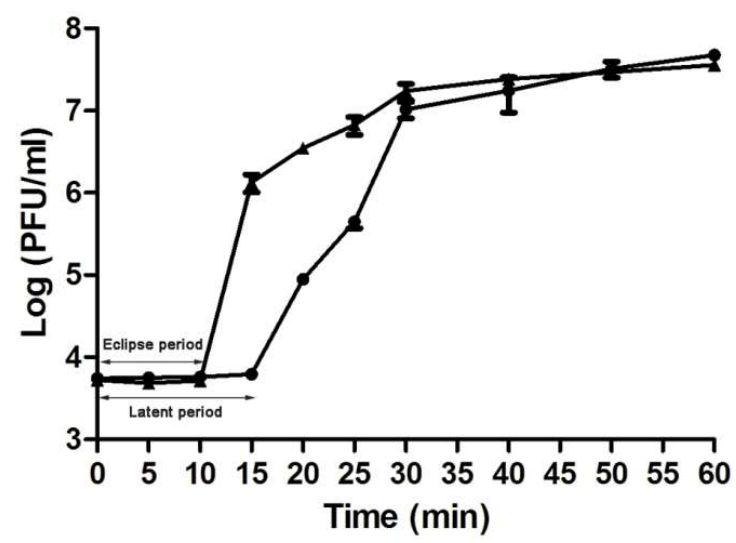

Figure 2. One-step growth curve for vB_AviM_AVP (AVP) in Aerococcus viridans AV-X1. Shown are samples treated with $(\boldsymbol{\Lambda})$ and without $(\bullet)$ chloroform at different time points. The values indicate means and standard deviations (SD) $(n=3)$.

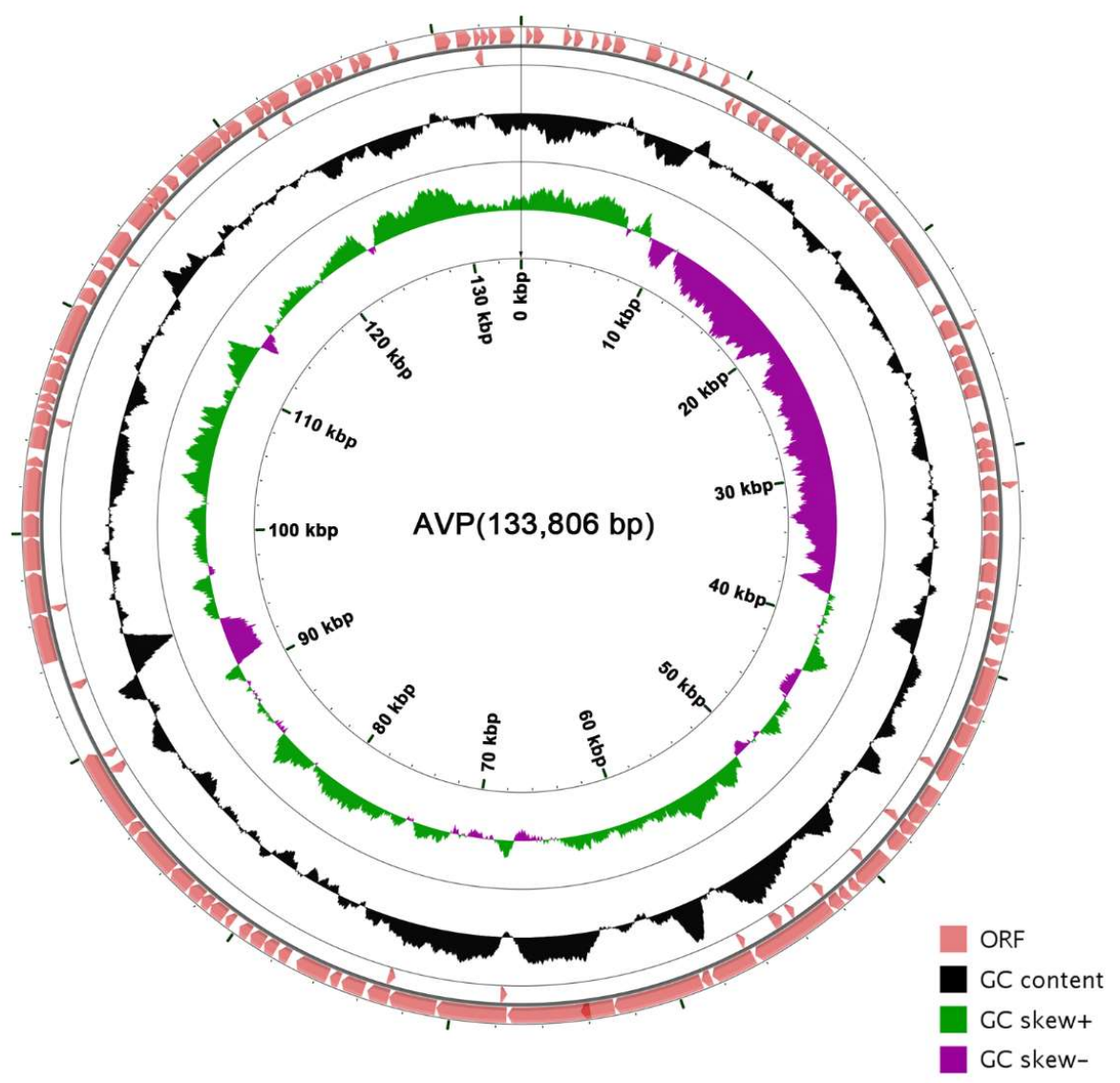

Figure 3. Genetic and physical organization of the vB_AviM_AVP (AVP) genome. The 165 ORFs of AVP are depicted, and the direction of transcription is indicated by arrows. The $\mathrm{G}+\mathrm{C}$ content and skew of AVP are also shown. The circle map of the AVP genome was made using CGView (http:/ / wishart.biology.ualberta.ca/cgview/) [40].

\subsection{The Putative ORFs of AVP}

The putative ORFs in the AVP genome were mapped (Figure 4). Among the predicted ORFs, 69 gene products exhibiting an identity similar $(\leq 65 \%)$ to proteins of known functions were tentatively 
assigned corresponding functions. In addition, 36 gene products did not match any viral or prokaryotic sequences in any publicly available database. On the basis of the putative functions of the ORFs, the genome of AVP was divided into three modules: nucleotide metabolism and replication, structural components, and lysis.

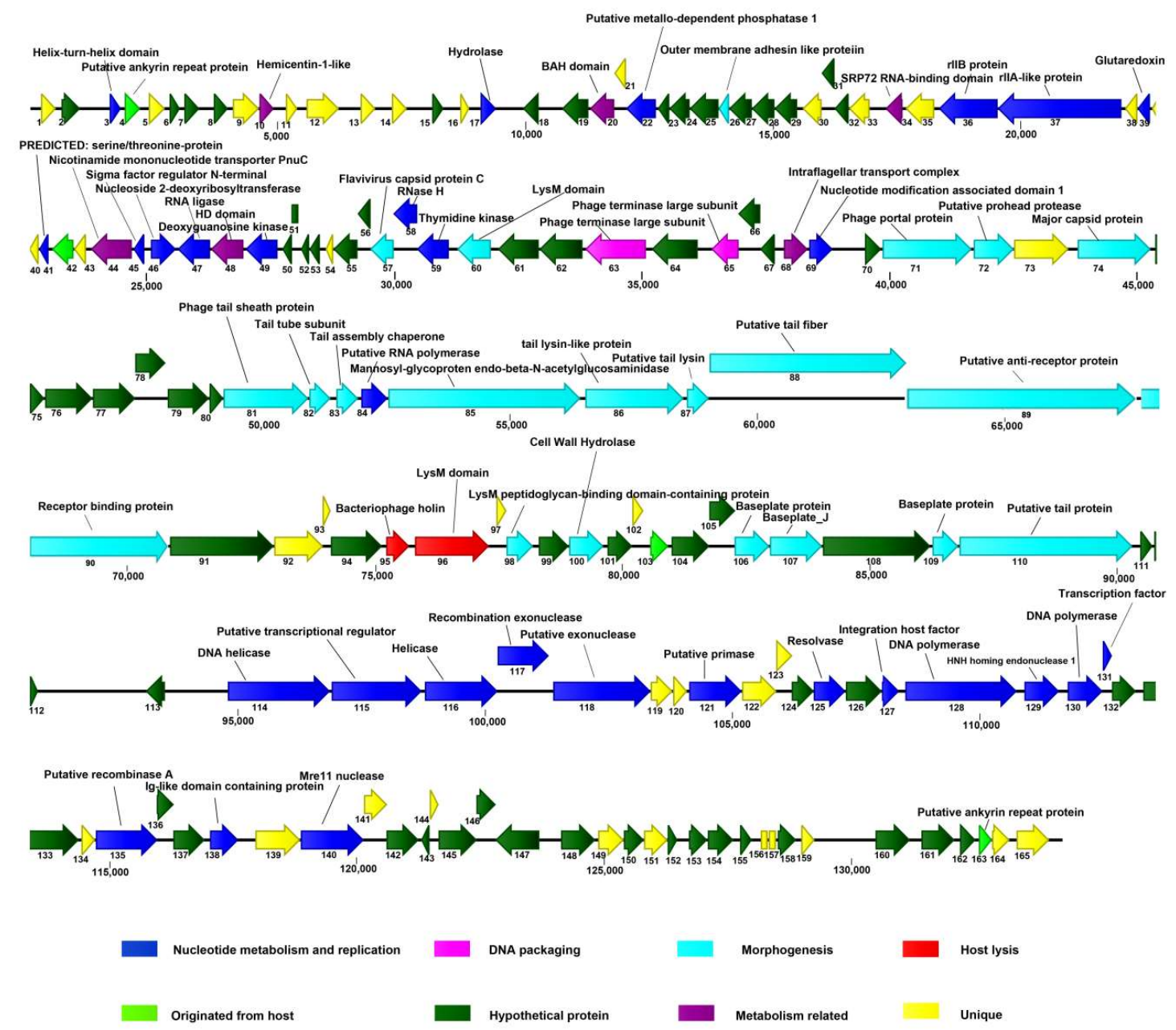

Figure 4. Graphical representation of the vB_AviM_AVP (AVP) genome. The 165 ORFs are depicted and the direction of transcription is indicated by arrows. Proposed modules are based on hypothetical functions predicted through bioinformatic analysis. The genome map was drawn using CLC Main Workbench, version 7.7.3 (CLC Bio-Qiagen, Aarhus, Denmark).

\subsection{The Lysis Module}

Three ORFs (ORF60, -96, and -98) in the AVP genome encode LysM peptidoglycan-binding domain-containing proteins, although only ORF96 is structurally adjacent to a putative holin (ORF95). Additionally, ORF100 encodes a cell wall hydrolase that hydrolyzes peptidoglycans, causing bacterial lysis. Considering that many genes encoding phage endolysins are adjacent to holin-encoding genes [28-30], especially phages of Gram-positive bacteria, ORF96 likely encodes an AVP endolysin. Interestingly, the lysis module (ORF95-ORF96) is located in the structure module. In addition, ORF98 encodes a protein that is homologous to the CHAP protein of Aerococcus sp., which may have a catalytic activity for peptidoglycan. Studies performed over the past decades have demonstrated that the LysM motif is involved in binding to bacterial peptidoglycan (PG), and LysM-containing hydrolases can hydrolyze bacterial PG [41,42]. Consequently, these putative LysM peptidoglycan-binding domain-containing proteins in AVP may work together to more efficiently hydrolyze the bacterial cell wall. The identity similarity among these four LysMs is very low, suggesting that they may act 
on different chemical bond of peptidoglycan. Additionally, the lack of similarity may be because no phage infecting $A$. viridans has been isolated before.

\subsection{The Nucleotide Metabolism and Replication Module}

The nucleotide metabolism and replication module of AVP is primarily located in two regions (1594-31,006 bp and 94,425-119,746 bp). Comparative analysis revealed that the following ORFs related to DNA replication were distributed in this module: DNA helicase (ORF114 and ORF116), putative transcriptional regulator (ORF115 and ORF131), exonuclease (ORF117 and ORF118), primase (ORF121), resolvase (ORF125), putative integration host factor (ORF127), polymerase (ORF128 and ORF130), recombinase A (ORF135), and Mre11 nuclease (ORF140). With respect to the 1594-31,006 bp region of this module, the putative products (ORF3, $-17,-22,-36,-37,-39,-41,-45,-46,-47,-49,-58$, and -59) are also possibly involved in DNA metabolism and replication.

ORF121 exhibited $\sim 50 \%$ amino acid identity with the putative primase of the Enterococcus phage EFP01. Owing to the semi-discontinuous nature of DNA replication, primases are required during the initiation and throughout the process of lagging strand replication [43]. Furthermore, primase can bind to the N-terminus of helicase to form a replicator, which has a wider role in DNA replication, repair, and possibly transcription.

A putative integration host factor encoded by ORF127 was also identified in this module, which can promote the assembly of a terminase motor complex [44], act as an activator of phage DNA replication [45], and is involved in the "decision" of a bacteriophage to end up with either the lytic or lysogenic cycle [46].

In addition, PSI-BLAST analysis showed that ORF128 and ORF130 of AVP encode two putative components which show homology with the N-terminal and C-terminal parts of the whole DNA polymerase, respectively. The data of Table S3 clearly indicate that the protein encoded by ORF129 showed similarity with HNH homing endonuclease (accession no. AUO79433.1), a site-specific DNA endonuclease that promotes the horizontal transfer of a gene and its flanking DNA [47]. Introns, including the homing endonuclease-like genes of the $\mathrm{HNH}$ superfamily, have been observed in the terminase large subunit gene of the Staphylococcus phage Twort $[48,49]$. Thus, the gene fragment between the genes ORF128 and ORF130 may be an inserted gene fragment (Figure S3). Group I introns have been reported to be capable of encoding homing endonucleases, which are responsible for placing the intron in the correct sequence context for efficient splicing [50]. Thus, the putative protein encoded by ORF129 may be responsible for intron mobility. Very interestingly, the N-terminal (ORF128) and C-terminal (ORF130) parts of the whole DNA polymerase can serve a normal function in the normal replication of AVP.

Of note, AVP was also observed to carry a gene (ORF45) encoding RNA polymerase sigma factor $\mathrm{N}$-terminal, an 8.8-kDa protein. RNA polymerase can be modified by this $\sigma$ factor to recognize phage-promoter regions, promoting the expression of phage genes rather than host genes [51]. Additionally, ORF115 and ORF131 encode putative transcriptional regulators that modify RNA polymerase to recognize phage-promoter regions, regulating gene expression such that phage genes are expressed rather than host genes, similar to the sigma factor of the staphylococcal phage [51]. Noticeably, ORF140 of AVP showed similarity to the Mre11 nuclease of the Staphylococcus phage phiIPLA-C1C. Interestingly, Mre11 was reported to play a role in DNA damage repair [52]. The protein encoded by ORF84 shows 36\% amino acid identity similarity to the putative RNA polymerase of the Enterococcus phage EFLK1 [53]. Interestingly, this ORF is located in the structural module.

\subsection{The Structure and Packaging Module}

The structural and packaging gene clusters were also identified in the AVP genome with the following order: terminase large subunit, terminase small subunit, portal protein, putative prohead protease, major capsid protein, and major tail sheath protein.

In particular, both the proteins encoded by ORF63 and ORF65 have short patches of similarity to other terminase large subunits. However, considering that the large subunit typically consists of 400-750 aa, while the small subunit typically contains $150-200$ aa, it is thought that the 405-aa protein encoded by 
ORF63 is a terminase large subunit, whereas the protein product of ORF65, which only contains 181 aa, is a terminase small subunit. Of these structure-associated products, ORF71 encodes the portal protein, which can form a channel in capsids and contributes to the injection of the bacteriophage genome into the host cell [54]. The proteins encoded by ORF72 and ORF74 showed similarities to the prohead protease of the Listeria phage LMTA-34 and the major capsid protein of the phage phiIPLA-C1C [55], respectively. The formation of the procapsid structure (also referred to as the prohead) initiates the morphogenesis of phages. During capsid maturation, the protease contained in the prohead is activated such that the inner core is destroyed and space for the genome is liberated [56,57].

Due to the conservation of the terminase large subunits and capsid proteins, they were used to generate a phylogenetic tree [58,59]. Given the small datasets, Bacillus phages are selected as the outgroup and we used maximum likelihood (ML) to generate the phylogenetic tree. The phages used in the phylogenetic tree analysis are the most closely related (top hits) to AVP on GENBANK at the protein level of the terminase large subunits and capsid proteins. As seen from Figure 5, according to the NCBI taxonomy database, the green-labeled leaves belong to the Spounavirinae subfamily. Other phages are not classified. At the level of the terminase large subunits, AVP and Staphylococcus phages are sister clade. On the other hand, AVP and Bacillus phages are sister clade in the phylogenetic tree of capsid. However, both phylogenetic trees indicated that the branch length of AVP is by far the longest branch length, suggesting AVP is phylogentically distant from all currently sequenced phages, such as Bacillus phages, Listeria phages, Staphylococcus phages and Enterococcus phages. The results indicate that AVP is a novel phage.

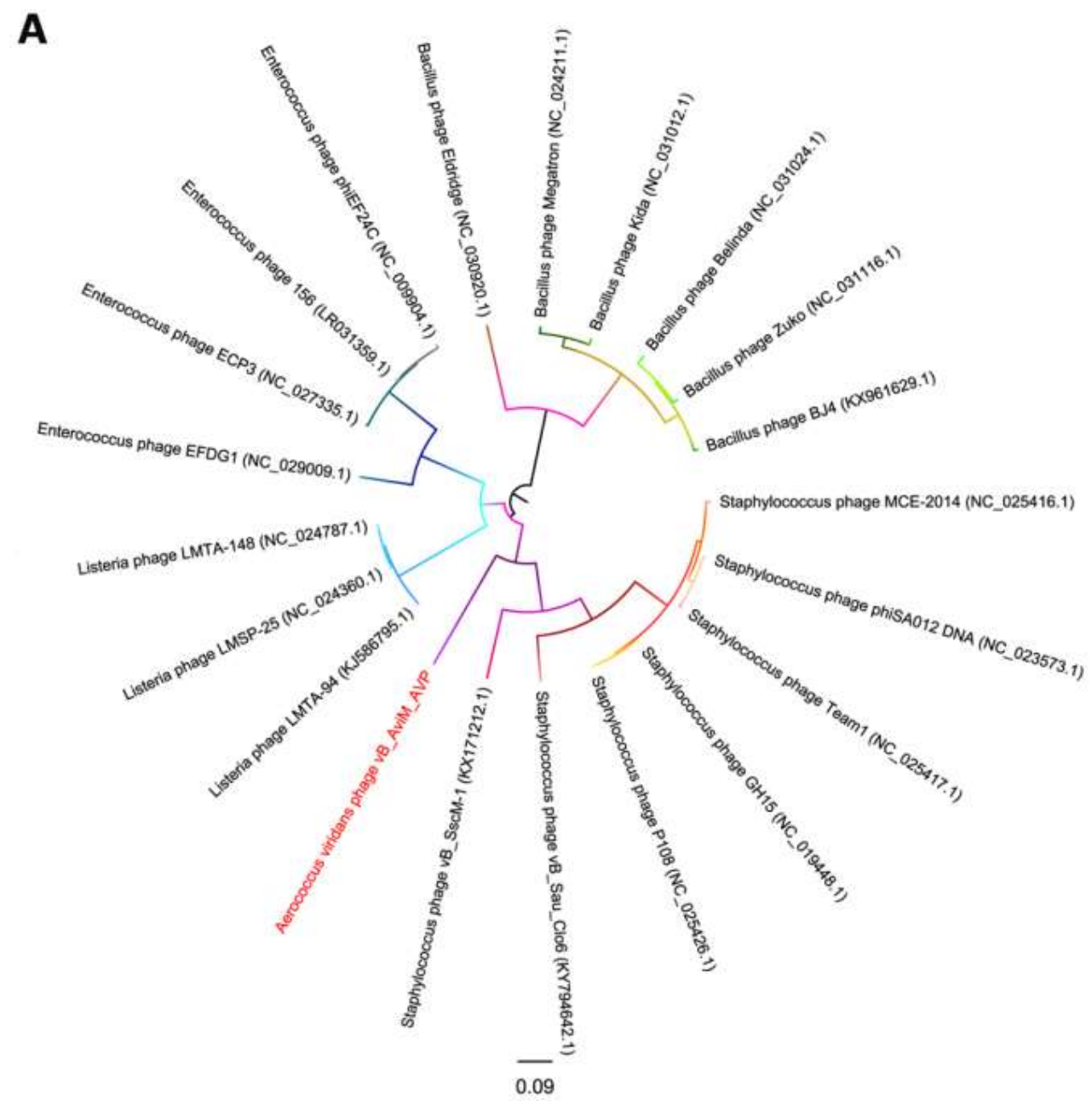

Figure 5. Cont. 


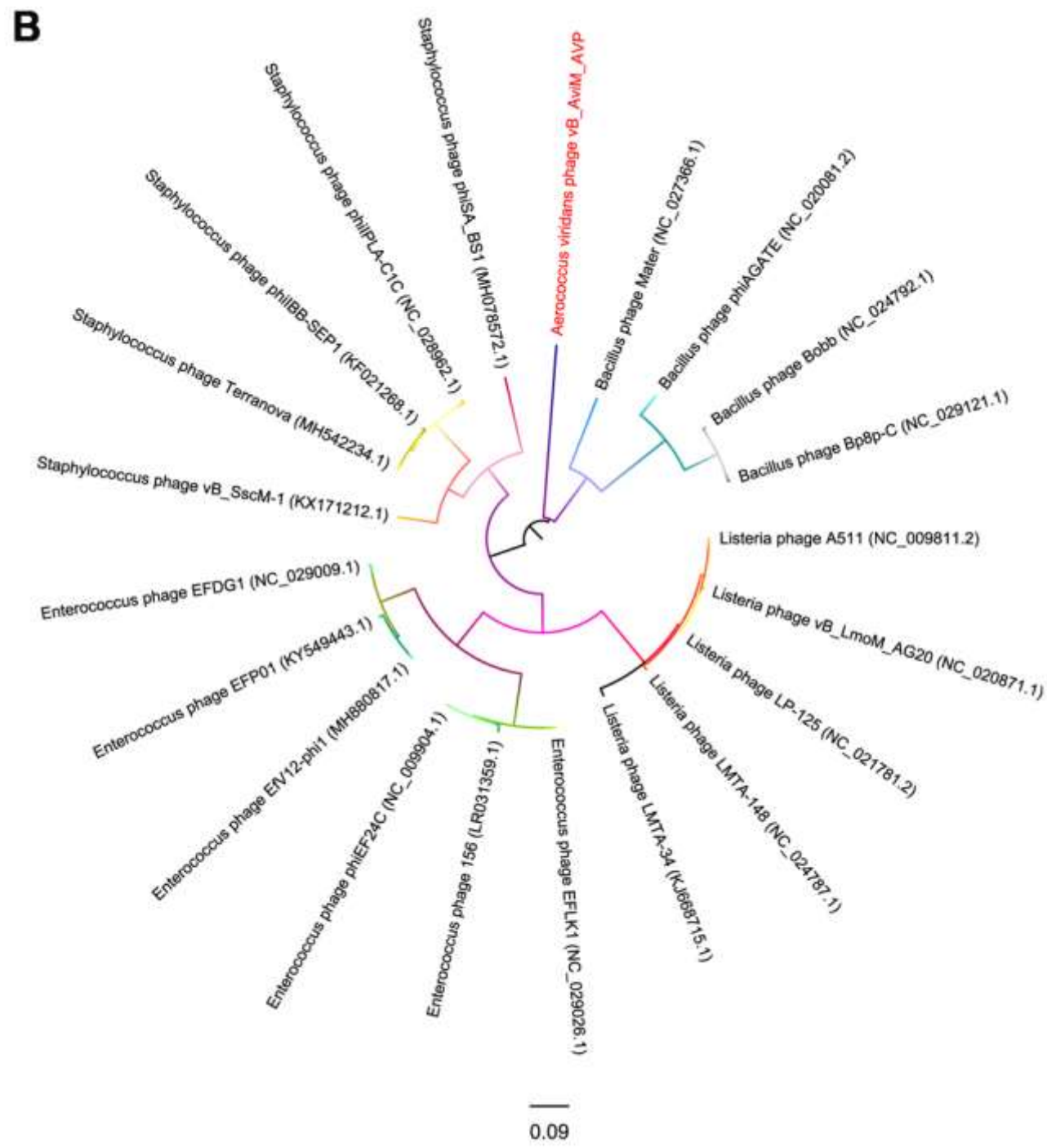

Figure 5. Phylogenetic tree based on the terminase large subunits (A) and capsid proteins (B) of selected phages. Both the terminase large subunits and capsid proteins were compared using PhyML version 3.0, and the phylogenetic trees were generated using the maximum likelihood method with 100 bootstrap replicates.

Six putative substructural proteins of the contractile tail of AVP were analyzed, of which the ORF81-ORF88 gene products are similar to the tail proteins of other phages. ORF81 encodes the putative tail sheath protein, which shows similarity to the sheath proteins from the published sequences of the Enterococcus phages EFP01 (APZ82006.1), EfV12-phi1 (AYJ73482.1), phiM1EF22 (BBE37297.1), phiEF24C (YP_001504132.1) [60], and ECP3 (YP_009147092.1). The sheath proteins are conserved in the sequence of many notoriously variable phage tail proteins. The protein encoded by ORF88 has $27-28 \%$ identity similarity to the tail fiber of these five Enterococcus phages.

In summary, we isolated and described the first phage that can infect $A$. viridans. The genome sequence, ORF alignment analysis, and phylogenetic tree analysis showed that AVP has extremely low similarity to other phages at the whole-genome nucleotide sequence level and at the amino acid sequence level. The observed characteristics of AVP indicate that it is a novel phage that represents a new class of phages. The results of this study have increased our understanding of phages and their diversity. 
Nucleotide Sequence Accession Numbers: The accession number of the $16 \mathrm{~S}$ sequence of $A$. viridans AV-X1 is MK281367 in the GenBank database. The accession number of the phage AVP is MH729379 in the GenBank database. The accession number of the raw fastq files is SRR8294366 in the GenBank database.

Supplementary Materials: The following are available online at http:/ /www.mdpi.com/1999-4915/11/2/104/s1.

Author Contributions: W.H., J.G., and Y.T. conceived and designed the experiments. H.X., J.D., F.Z., and H.F. performed the experiments. H.X. and Y.T. wrote the manuscript. M.C., X.L., R.C., and Y.J. conducted data collection and analysis and drafted the manuscript. C.S., X.F., and S.u.R. read and revised the manuscript.

Funding: This work was financially supported through grants from the National Natural Science Foundation of China (No. 31872505, 31502103, and 31572553), the Jilin Province Science Foundation for Youths (Changchun, China; grant no. 20190103106JH) and the National Key Research and Development Program of China (No. 2018YFD0500504).

Acknowledgments: We also give our special thanks to Zhimin Guo from the Department of Clinical Laboratory, The First Hospital of Jilin University, Jilin University, P.R. China, for identifying the A. viridans AV-X1.

Conflicts of Interest: The authors declare no competing financial interests.

\section{References}

1. Sun, M.; Gao, J.; Ali, T.; Yu, D.; Zhang, S.; Khan, S.U.; Fanning, S.; Han, B. Characteristics of Aerococcus viridans isolated from bovine subclinical mastitis and its effect on milk SCC, yield, and composition. Trop. Anim. Health Prod. 2017, 49, 843-849. [CrossRef] [PubMed]

2. Rasmussen, M. Aerococci and aerococcal infections. J. Infect. 2013, 66, 467-474. [CrossRef] [PubMed]

3. Pan, Z.; Ma, Y.; Ma, J.; Dong, W.; Yao, H. Acute meningitis of piglets and mice caused by co-infected with Streptococcus suis and Aerococcus viridans. Microb. Pathog. 2017, 106, 60-64. [CrossRef] [PubMed]

4. Kerbaugh, M.A.; Evans, J.B. Aerococcus viridans in the hospital environment. Appl. Microbiol. 1968, 16, 519-523. [PubMed]

5. Stebbing, P.D.; Pond, M.J.; Peeler, E.; Small, H.J.; Greenwood, S.J.; Verner-Jeffreys, D. Limited prevalence of gaffkaemia (Aerococcus viridans var. homari) isolated from wild-caught European lobsters Homarus gammarus in England and Wales. Dis. Aquat. Organ. 2012, 100, 159-167. [CrossRef] [PubMed]

6. Ke, X.; Lu, M.; Ye, X.; Gao, F.; Zhu, H.; Huang, Z. Recovery and pathogenicity analysis of Aerococcus viridans isolated from tilapia (Orecohromis niloticus) cultured in southwest of China. Aquaculture 2012, 342-343, 18-23. [CrossRef]

7. Martin, V.; Vela, A.I.; Gilbert, M.; Cebolla, J.; Goyache, J.; Dominguez, L.; Fernandez-Garayzabal, J.F. Characterization of Aerococcus viridans isolates from swine clinical specimens. J. Clin. Microbiol. 2007, 45, 3053-3057. [CrossRef]

8. Liu, G.; Liu, Y.; Ali, T.; Ferreri, M.; Gao, J.; Chen, W.; Yin, J.; Su, J.; Fanning, S.; Han, B. Molecular and Phenotypic Characterization of Aerococcus viridans Associated with Subclinical Bovine Mastitis. PLoS ONE 2015, 10, e0125001. [CrossRef]

9. Saishu, N.; Morimoto, K.; Yamasato, H.; Ozaki, H.; Murase, T. Characterization of Aerococcus viridans isolated from milk samples from cows with mastitis and manure samples. J. Vet. Med. Sci. 2015, 77, 1037-1042. [CrossRef]

10. Zadoks, R.N.; Gonzalez, R.N.; Boor, K.J.; Schukken, Y.H. Mastitis-causing streptococci are important contributors to bacterial counts in raw bulk tank milk. J. Food Prot. 2004, 67, 2644-2650. [CrossRef]

11. Spakova, T.; Elecko, J.; Vasil, M.; Legath, J.; Pristas, P.; Javorsky, P. Limited genetic diversity of Aerococcus viridans strains isolated from clinical and subclinical cases of bovine mastitis in Slovakia. Pol. J. Vet. Sci. 2012, 15, 329-335. [CrossRef] [PubMed]

12. Gopalachar, A.; Akins, R.L.; Davis, W.R.; Siddiqui, A.A. Urinary tract infection caused by Aerococcus viridans, a case report. Med. Sci. Monit. Int. Med. J. Exp. Clin. Res. 2004, 10, CS73-CS75.

13. Uh, Y.; Son, J.S.; Jang, I.H.; Yoon, K.J.; Hong, S.K. Penicillin-resistant Aerococcus viridans bacteremia associated with granulocytopenia. J. Korean Med. Sci. 2002, 17, 113-115. [CrossRef] [PubMed]

14. Nathavitharana, K.A.; Arseculeratne, S.N.; Aponso, H.A.; Vijeratnam, R.; Jayasena, L.; Navaratnam, C. Acute meningitis in early childhood caused by Aerococcus viridans. Br. Med. J. 1983, 286, 1248. [CrossRef]

15. Facklam, R.; Elliott, J.A. Identification, classification, and clinical relevance of catalase-negative, gram-positive cocci, excluding the streptococci and enterococci. Clin. Microbiol. Rev. 1995, 8, 479-495. [CrossRef] 
16. Popescu, G.A.; Benea, E.; Mitache, E.; Piper, C.; Horstkotte, D. An unusual bacterium, Aerococcus viridans, and four cases of infective endocarditis. J. Heart Valve Dis. 2005, 14, 317-319. [PubMed]

17. Buu-Hoi, A.; Le Bouguenec, C.; Horaud, T. Genetic basis of antibiotic resistance in Aerococcus viridans. Antimicrob. Agents Chemother. 1989, 33, 529-534. [CrossRef]

18. Zhou, W.Q.; Niu, D.M.; Zhang, Z.Z.; Ning, M.Z.; Shen, H.; Zhang, K. Vancomycin resistance due to VanA in an Aerococcus viridans isolate. Indian J. Med. Microbiol. 2014, 32, 462-465.

19. Hatfull, G.F.; Hendrix, R.W. Bacteriophages and their genomes. Curr. Opin. Virol. 2011, 1, 298-303. [CrossRef]

20. Karpe, Y.A.; Kanade, G.D.; Pingale, K.D.; Arankalle, V.A.; Banerjee, K. Genomic characterization of Salmonella bacteriophages isolated from India. Virus Genes 2016, 52, 117-126. [CrossRef]

21. Gu, J.; Liu, X.; Li, Y.; Han, W.; Lei, L.; Yang, Y.; Zhao, H.; Gao, Y.; Song, J.; Lu, R.; et al. A method for generation phage cocktail with great therapeutic potential. PLoS ONE 2012, 7, e31698. [CrossRef] [PubMed]

22. Sulakvelidze, A.; Alavidze, Z.; Morris, J.G., Jr. Bacteriophage therapy. Antimicrob. Agents Chemother. 2001, 45, 649-659. [CrossRef] [PubMed]

23. Kropinski, A.M.; Waddell, T.; Meng, J.; Franklin, K.; Ackermann, H.W.; Ahmed, R.; Mazzocco, A.; Yates, J., 3rd; Lingohr, E.J.; Johnson, R.P. The host-range, genomics and proteomics of Escherichia coli O157:H7 bacteriophage rV5. Virol. J. 2013, 10, 76. [CrossRef] [PubMed]

24. Lv, M.; Wang, S.; Yan, G.; Sun, C.; Feng, X.; Gu, J.; Han, W.; Lei, L. Genome sequencing and analysis of an Escherichia coli phage vB_EcoM-ep3 with a novel lysin, Lysep3. Virus Genes 2015, 50, 487-497. [CrossRef] [PubMed]

25. Habann, M.; Leiman, P.G.; Vandersteegen, K.; Van den Bossche, A.; Lavigne, R.; Shneider, M.M.; Bielmann, R.; Eugster, M.R.; Loessner, M.J.; Klumpp, J. Listeria phage A511, a model for the contractile tail machineries of SPO1-related bacteriophages. Mol. Microbiol. 2014, 92, 84-99. [CrossRef] [PubMed]

26. Denes, T.; Vongkamjan, K.; Ackermann, H.W.; Moreno Switt, A.I.; Wiedmann, M.; den Bakker, H.C. Comparative genomic and morphological analyses of Listeria phages isolated from farm environments. Appl. Environ. Microbiol. 2014, 80, 4616-4625. [CrossRef] [PubMed]

27. Kwiatek, M.; Parasion, S.; Mizak, L.; Gryko, R.; Bartoszcze, M.; Kocik, J. Characterization of a bacteriophage, isolated from a cow with mastitis, that is lytic against Staphylococcus aureus strains. Arch. Virol. 2012, 157, 225-234. [CrossRef]

28. Jia, H.; Dong, W.; Yuan, L.; Ma, J.; Bai, Q.; Pan, Z.; Lu, C.; Yao, H. Characterization and complete genome sequence analysis of Staphylococcus aureus bacteriophage JS01. Virus Genes 2015, 50, 345-348. [CrossRef]

29. Bai, Q.; Zhang, W.; Yang, Y.; Tang, F.; Nguyen, X.; Liu, G.; Lu, C. Characterization and genome sequencing of a novel bacteriophage infecting Streptococcus agalactiae with high similarity to a phage from Streptococcus pyogenes. Arch. Virol. 2013, 158, 1733-1741. [CrossRef]

30. Dalmasso, M.; de Haas, E.; Neve, H.; Strain, R.; Cousin, F.J.; Stockdale, S.R.; Ross, R.P.; Hill, C. Isolation of a Novel Phage with Activity against Streptococcus mutans Biofilms. PLoS ONE 2015, 10, e0138651. [CrossRef]

31. Grant, K.A.; Dickinson, J.H.; Collins, M.D.; Kroll, R.G. Rapid identification of Aerococcus viridans using the polymerase chain reaction and an oligonucleotide probe. FEMS Microbiol. Lett. 1992, 74, 63-69. [CrossRef] [PubMed]

32. Gu, J.; Xu, W.; Lei, L.; Huang, J.; Feng, X.; Sun, C.; Du, C.; Zuo, J.; Li, Y.; Du, T.; et al. LysGH15, a novel bacteriophage lysin, protects a murine bacteremia model efficiently against lethal methicillin-resistant Staphylococcus aureus infection. J. Clin. Microbiol. 2011, 49, 111-117. [CrossRef] [PubMed]

33. Saralamba, N.; Mayxay, M.; Newton, P.N.; Smithuis, F.; Nosten, F.; Archasuksan, L.; Pukrittayakamee, S.; White, N.J.; Day, N.P.J.; Dondorp, A.M.; et al. Genetic polymorphisms in the circumsporozoite protein of Plasmodium malariae show a geographical bias. Malar. J. 2018, 17, 269. [CrossRef] [PubMed]

34. Gadagkar, R.; Gopinathan, K.P. Bacteriophage burst size during multiple infections. J. Biosci. 1980, 2, $253-259$. [CrossRef]

35. Aziz, R.K.; Bartels, D.; Best, A.A.; DeJongh, M.; Disz, T.; Edwards, R.A.; Formsma, K.; Gerdes, S.; Glass, E.M.; Kubal, M.; et al. The RAST Server: Rapid annotations using subsystems technology. BMC Genom. 2008, 9, 75. [CrossRef] [PubMed]

36. Altschul, S.F.; Madden, T.L.; Schaffer, A.A.; Zhang, J.; Zhang, Z.; Miller, W.; Lipman, D.J. Gapped BLAST and PSI-BLAST: A new generation of protein database search programs. Nucleic Acids Res. 1997, 25, 3389-3402. [CrossRef] 
37. Lowe, T.M.; Chan, P.P. tRNAscan-SE On-line: Search and Contextual Analysis of Transfer RNA Genes. Nucleic Acids Res. 2016, 44, W54-W57. [CrossRef]

38. Guindon, S.; Dufayard, J.F.; Lefort, V.; Anisimova, M.; Hordijk, W.; Gascuel, O. New algorithms and methods to estimate maximum-likelihood phylogenies: Assessing the performance of PhyML 3.0. Syst. Biol. 2010, 59, 307-321. [CrossRef]

39. Carkaci, D.; Dargis, R.; Nielsen, X.C.; Skovgaard, O.; Fuursted, K.; Christensen, J.J. Complete Genome Sequences of Aerococcus christensenii CCUG 28831T, Aerococcus sanguinicola CCUG 43001T, Aerococcus urinae CCUG 36881T, Aerococcus urinaeequi CCUG 28094T, Aerococcus urinaehominis CCUG 42038 BT, and Aerococcus viridans CCUG 4311T. Genome Announc. 2016, 4, e00302-16. [CrossRef]

40. Stothard, P.; Wishart, D.S. Circular genome visualization and exploration using CGView. Bioinformatics 2005, 21, 537-539. [CrossRef]

41. Visweswaran, G.R.; Leenhouts, K.; van Roosmalen, M.; Kok, J.; Buist, G. Exploiting the peptidoglycan-binding motif, LysM, for medical and industrial applications. Appl. Microbiol. Biotechnol. 2014, 98, 4331-4345. [CrossRef] [PubMed]

42. Hu, S.; Kong, J.; Kong, W.; Guo, T.; Ji, M. Characterization of a novel LysM domain from Lactobacillus fermentum bacteriophage endolysin and its use as an anchor to display heterologous proteins on the surfaces of lactic acid bacteria. Appl. Environ. Microbiol. 2010, 76, 2410-2418. [CrossRef] [PubMed]

43. Guilliam, T.A.; Keen, B.A.; Brissett, N.C.; Doherty, A.J. Primase-polymerases are a functionally diverse superfamily of replication and repair enzymes. Nucleic Acids Res. 2015, 43, 6651-6664. [CrossRef] [PubMed]

44. Sanyal, S.J.; Yang, T.C.; Catalano, C.E. Integration host factor assembly at the cohesive end site of the bacteriophage lambda genome: Implications for viral DNA packaging and bacterial gene regulation. Biochemistry 2014, 53, 7459-7470. [CrossRef] [PubMed]

45. Greenstein, D.; Zinder, N.D.; Horiuchi, K. Integration host factor interacts with the DNA replication enhancer of filamentous phage f1. Proc. Natl. Acad. Sci. USA 1988, 85, 6262-6266. [CrossRef]

46. Saha, S.; Haggard-Ljungquist, E.; Nordstrom, K. Integration host factor is necessary for lysogenization of Escherichia coli by bacteriophage P2. Mol. Microbiol. 1990, 4, 3-11. [CrossRef]

47. Bonocora, R.P.; Belfort, M. Mapping homing endonuclease cleavage sites using in vitro generated protein. Methods Mol. Biol. 2014, 1123, 55-67.

48. Kwan, T.; Liu, J.; DuBow, M.; Gros, P.; Pelletier, J. The complete genomes and proteomes of 27 Staphylococcus aureus bacteriophages. Proc. Natl. Acad. Sci. USA 2005, 102, 5174-5179. [CrossRef]

49. Gu, J.; Liu, X.; Yang, M.; Li, Y.; Sun, C.; Lu, R.; Song, J.; Zhang, Q.; Lei, L.; Feng, X.; et al. Genomic characterization of lytic Staphylococcus aureus phage GH15: Providing new clues to intron shift in phages. J. Gen. Virol. 2013, 94 Pt 4, 906-915. [CrossRef]

50. Foley, S.; Bruttin, A.; Brussow, H. Widespread distribution of a group I intron and its three deletion derivatives in the lysin gene of Streptococcus thermophilus bacteriophages. J. Virol. 2000, 74, 611-618. [CrossRef]

51. O'Flaherty, S.; Coffey, A.; Edwards, R.; Meaney, W.; Fitzgerald, G.F.; Ross, R.P. Genome of staphylococcal phage K: A new lineage of Myoviridae infecting gram-positive bacteria with a low $\mathrm{G}+\mathrm{C}$ content. J. Bacteriol. 2004, 186, 2862-2871. [CrossRef] [PubMed]

52. Buis, J.; Wu, Y.; Deng, Y.; Leddon, J.; Westfield, G.; Eckersdorff, M.; Sekiguchi, J.M.; Chang, S.; Ferguson, D.O. Mre11 nuclease activity has essential roles in DNA repair and genomic stability distinct from ATM activation. Cell 2008, 135, 85-96. [CrossRef] [PubMed]

53. Khalifa, L.; Coppenhagen-Glazer, S.; Shlezinger, M.; Kott-Gutkowski, M.; Adini, O.; Beyth, N.; Hazan, R. Complete Genome Sequence of Enterococcus Bacteriophage EFLK1. Genome Announc. 2015, 3, e01308-15. [CrossRef] [PubMed]

54. Casjens, S.; Hendrix, R. Control Mechanisms in dsDNA Bacteriophage Assembly. In The Bacteriophages; Springer: Basel, Switzerland, 1988; Chapter 2; pp. 15-91.

55. Gutierrez, D.; Vandenheuvel, D.; Martinez, B.; Rodriguez, A.; Lavigne, R.; Garcia, P. Two Phages, phiIPLA-RODI and phiIPLA-C1C, Lyse Mono- and Dual-Species Staphylococcal Biofilms. Appl. Environ. Microbiol. 2015, 81, 3336-3348. [CrossRef] [PubMed]

56. Droge, A.; Tavares, P. In vitro packaging of DNA of the Bacillus subtilis bacteriophage SPP1. J. Mol. Biol. 2000, 296, 103-115. [CrossRef] [PubMed]

57. Fokine, A.; Rossmann, M.G. Common Evolutionary Origin of Procapsid Proteases, Phage Tail Tubes, and Tubes of Bacterial Type VI Secretion Systems. Structure 2016, 24, 1928-1935. [CrossRef] [PubMed] 
58. Casjens, S.R.; Gilcrease, E.B.; Winn-Stapley, D.A.; Schicklmaier, P.; Schmieger, H.; Pedulla, M.L.; Ford, M.E.; Houtz, J.M.; Hatfull, G.F.; Hendrix, R.W. The generalized transducing Salmonella bacteriophage ES18: Complete genome sequence and DNA packaging strategy. J. Bacteriol. 2005, 187, 1091-1104. [CrossRef]

59. Rossmann, M.G. Structure of viruses: A short history. Q. Rev. Biophys. 2013, 46, 133-180. [CrossRef]

60. Uchiyama, J.; Rashel, M.; Takemura, I.; Wakiguchi, H.; Matsuzaki, S. In silico and in vivo evaluation of bacteriophage phiEF24C, a candidate for treatment of Enterococcus faecalis infections. Appl. Environ. Microbiol. 2008, 74, 4149-4163. [CrossRef]

C 2019 by the authors. Licensee MDPI, Basel, Switzerland. This article is an open access article distributed under the terms and conditions of the Creative Commons Attribution (CC BY) license (http://creativecommons.org/licenses/by/4.0/). 